\title{
Isolation and Identification of Nematicidal Principle in Lippia nodiflora against Root Knot Nematode Meloidogyne incognita
}

\author{
T. Senthilkumar* and S. Ramakrishnan \\ Department of Nematology, TNAU, Coimbatore - 641003 \\ *Corresponding author
}

\section{A B S T R A C T}

\begin{tabular}{|c|}
\hline \\
\hline $\begin{array}{l}\text { Lippia nodiflora, } \\
\text { Nematicidal } \\
\text { compounds, Phenols, } \\
\text { Alkaioids, root knot } \\
\text { nematode, } \\
\text { Meloidogyne incognita }\end{array}$ \\
\hline Article Info \\
\hline $\begin{array}{l}\text { Accepted: } \\
17 \text { November } 2018 \\
\text { Available Online: } \\
10 \text { December } 2018\end{array}$ \\
\hline
\end{tabular}

\section{Keywords}

Lippia nodiflora Alkaioids, root knot nematode,

gyne incognita

\section{Introduction}

The root knot nematode Meloidogyne incognita is a serious threat to the cultivation of agriculture and horticultural crops all over the world. Management of root knot nematodes through nematicides not only polluting the environment and also results in health hazards due to their residual effects. Natural plant products are considered as important source of biopesticide and an alternative to chemicals being used in the management of plant diseases. Recent studies have shown that the importance of plant
The protein and non protein parts present in the leaves of Lippia nodiflora were separated and test their nematicidal activity against egg hatching and juvenile mortality of Meloidogyne incognita. The non protein part was found to inhibit the root knot nematode egg hatching under in vitro conditions. Leaf extraction was done with different solvent such as petroleum ether, chloroform methanol using soxhlet apparatus and the residue was discarded. Thin layer chromatography method was used to isolate and identify the nematicidal principle present in Lippia nodiflora. The dentified compounds in non protein parts such as phenols, alkaloids and terpenoids ere tested for their nematicidal activity on egg hatching and mortality of $M$. ognita juveniles. The nematicidal assay of these compounds revealed that the aloids inhibited egg hatching absolutely and caused juvenile mortality followed by causing mortality of juveniles of $M$. incognita. 
elucidated. The isolation and identification of nematicidal principle of the phytochemicals will be helpful in synthesizing novel bionematicide. Keeping this in view the present study was taken up to identify the nematicidal compounds present in Lippianodiflora.

\section{Materials and Methods}

Separation of the protein and non-protein part from the leaf extracts

The protein and non-protein part was separated from the aqueous leaf extract by the method given by Bradford (1976). A sample of $40 \mathrm{~g}$ fresh leaves of Lippianodiflora was macerated with $100 \mathrm{ml}$ distilled water using pestle and mortar. The aqueous extract was filtered through a four play muslin cloth in order to remove plant debris and then centrifuged for five minutes at $4000 \mathrm{rpm}$ under $4^{\circ} \mathrm{C}$. Ammonium sulphate $(52.3 \mathrm{~g})$ was added to the supernatant solution and it was kept overnight in a refrigerator followed by centrifugation at $10,000 \mathrm{rpm}$ under $4^{\circ} \mathrm{C}$ for 20 minutes. The supernatant of the sample of non-protein part was transferred to separate flasks. The pellet, settled at the bottom was the protein part and it was dissolved in equal quantity of sterile distilled water and transferred to dialysis tubes, kept in a beaker filled with water. The water was changed every $12 \mathrm{~h}$ for one day and stored in a refrigerator. This dialysis was done to discard the ammonium sulphate from protein part. Thereafter the resultant protein and nonprotein part were taken for hatching study to check which part was inhibitory in nature.

\section{Hatching study}

One $\mathrm{ml}$ of protein part and $9 \mathrm{ml}$ of distilled water was pipette out into petri dishes. Likewise $1 \mathrm{ml}$ of non-protein part and $9 \mathrm{ml}$ of distilled water was pipette out into petri dishes. Single egg mass was transferred into each petri dish containing test compound. One egg mass taken in $10 \mathrm{ml}$ distilled water was served as control. Number of juveniles hatched was recorded every day up to seven days.

\section{Leaf extraction by different solvent using Soxhlet apparatus}

Fresh leaf material was cut into small pieces and ground well after drying in oven at $60^{\circ} \mathrm{C}$ for 48 hours. Leaf extraction was done with petroleum ether $\left(40-60^{\circ} \mathrm{C}\right)$ from the leaf powder thimble in a filter paper and kept in soxhlet apparatus. The crude petroleum ether extract was collected and the residue was again used for chloroform extract. The crude petroleum ether extract was collected and the residue was again used for chloroform extract. The crude chloroform extract was collected and the residue was again used for methanol extract. Crude methanol extract was collected and the residue was discarded.

\section{Identification of the nematicidal compound using Thin Layer Chromatography (Srivastava and Srivastava, 1991)}

\section{Preparation and activation of TLC plate}

Thin layer chromatography method was used to isolate and identify the nematicidal principle in Lippia nodiflora. Silica Gel-G was used for preparing TLC plates $(20 \times 20 \mathrm{~cm})$. Powdered silica gel weighing $40 \mathrm{~g}$ was thoroughly mixed with $80 \mathrm{ml}$ of distilled water. The slurry was then poured into TLC applicator, which was adjusted for $0.5 \mathrm{~mm}$ thickness and it was slowly moved o the clean glass plate. The glass plates were allowed to dry in open air for an hour. Then the glass plate with silica gel coating was heated in an oven at $110^{\circ} \mathrm{C}$ for 2 hours. Thus the TLC plate was activated. After activation of the TLC plate, sample $(20 \mu 1)$ was spotted on the plate with the help of micropipette without disturbing the silica gel layer. 


\section{Separation of compounds}

The solvent systems used were acetic acid: chloroform (1:9), methanol: chloroform (1:9) and chloroform: methanol (1:1). The solvent was poured into the TLC tank and then the TLC plate was kept into the tank so as to immerse $(0.5 \mathrm{~cm})$ into solvent at the bottom. The tank was closed with a glass lid so as the chamber filled with the solvent vapours completely. Within two hours the solvent front reaches the end of the TLC plates. Then the plate was removed from the tank and kept in open air at room temperature so as to enable the solvent to get evaporated. Then the plates were sprayed with chromogenic reagent like Ten per cent Vanillin-Sulphuric acid, Dragendorff's reagent, Diazotized sulphailic acid solution, Folin-Ciocalteau reagent, Ethanolic Alumionium chloride, Methanolic $\mathrm{KOH}$ so as to identify the compounds present in the leaf extract based on the coloured spots and the Rf (Relative front= Distance moved by the solute from the origin/Distance moved by the solvent from the origin) values were recorded. To screen the saponins, a small amount of all the three crude extract was placed in test tubes and to it $2 \mathrm{ml}$ of water was added. The tubes were shaken vigorously and the formation of persistent foam was indicated the presence of saponins. A drop of methyl alcohol was added to enhance the further formation of foam. After development of the compounds, the corresponding place was scraped off. This scraped off material was eluted with methanol and recovered in a relatively pure form. This was used for egg hatching and mortality study to confirm the nematicidal action.

\section{Hatching study}

One egg mass was transferred into each petri dish containing eluted compound. One egg mass taken in $10 \mathrm{ml}$ distilled water was served as control. Number of juveniles hatched was recorded seven days after initiation.

\section{Mortality test}

The nematode, $M$. incognita inoculum required for the experiment was obtained from Coleus sp. Raised in glasshouse. The egg masses were collected from the pure culture and incubated for hatching at room temperature for seven days. Freshly hatched second stage juveniles were used for mortality test. Hundred juveniles were introduced in each petridish containing eluted compound and petridish with distilled water was served as control.

\section{Results and Discussion}

The protein and non-protein part of aqueous leaf extracts were tested for their influence on egg hatching under laboratory conditions. The protein part was found to have lesser inhibition effect compared to non-protein part (Table 1) as 343 juveniles were hatched from one egg mass in protein part, and it was only 5 in non protein part on $7^{\text {th }}$ day of exposure.

\section{Detection of active compounds by thin layer chromatography}

The petroleum ether, chloroform and methanol extracts of Lippia nodiflora leaves were prepared and subjected to thin layer chromatography using different solvent systems and different chromogenic reagents. The few spots with different $\mathrm{Rf}$ values were observed in TLC plates on visual observation. The spots were identified based on the colour formation after spraying of different chromogenic reagents (Table 2).

\section{Phenolic compounds}

The phenolic compounds from leaf extracts were separated by TLC with acetic acid: chloroform (1:9) as solvent, and diazotized sulphanilic acid and folin-ciocalteau reagent as chromogenic reagent. Single circular spot with $\mathrm{Rf}$ value of 0.842 appeared as orange 
colour when sprayed with diazotized sulphanilic acid. Similarly spot with $\mathrm{Rf}$ values of 0.843 appeared as bluish when sprayed with folinciocalteau reagent. Orange and bluish coloured spots indicated the presence of the phenolic compounds.

\section{Terpenoid compounds}

The solvent of methanol: chloroform (1:9) and 10 per cent vanillin sulphuric acid was used for isolation of terpenoid compounds from the leaf extract. Three spots were noticed which turned into greenish spot when sprayed with
$10 \%$ vanillin sulphruic acid which indicated the presence of terpenoid compounds.

\section{Alkaloid compounds}

In order to separate alkaloids from leaf extracts, the solvent chloroform: methanol (1:1) and Dragendorffs reagent were used. Presence of three spots was noticed on visual observation. Single spot with $\mathrm{Rf}$ value of 0.892 turned into yellow colour when sprayed with Dragendorff's reagent which indicated the presence of alkaloid compounds.

Table.1 Effect of protein and non protein part on egg hatching of M. incognita

\begin{tabular}{|l|l|l|l|l|l|l|l|}
\hline \multirow{2}{*}{ Leaf extract } & \multicolumn{5}{|c|}{ Number of juveniles at different days of intervals } \\
\cline { 2 - 8 } & 1 & 2 & 3 & 4 & 5 & 6 & 7 \\
\hline Protein part & 269 & 284 & 320 & 336 & 342 & 342 & 343 \\
\hline Non-protein part & - & - & 4 & 4 & 5 & 5 & 5 \\
\hline Control & 332 & 350 & 369 & 375 & 387 & 387 & 387 \\
\hline
\end{tabular}

Table.2 Rf values of different spots on visual observation and compounds sprayed with different reagent in the isolation of nematicidal principles using TLC

\begin{tabular}{|l|l|l|l|l|l|l|l|}
\hline \multirow{2}{*}{$\begin{array}{l}\text { Chromogenic } \\
\text { reagent }\end{array}$} & \multicolumn{2}{|c|}{ Petroleum ether } & \multicolumn{2}{c|}{ chloroform } & \multicolumn{2}{c|}{ Methanol } \\
\cline { 2 - 8 } & $\begin{array}{l}\text { Visual } \\
\text { Obser } \\
\text { vation }\end{array}$ & $\begin{array}{l}\text { Colour of } \\
\text { Nematicidal } \\
\text { Compounds }\end{array}$ & $\begin{array}{l}\text { Visual } \\
\text { observation }\end{array}$ & $\begin{array}{l}\text { Colour of } \\
\text { Nematicidal } \\
\text { Compounds }\end{array}$ & $\begin{array}{l}\text { Visual } \\
\text { observation }\end{array}$ & $\begin{array}{l}\text { Colour of } \\
\text { Nematicidal } \\
\text { Compounds }\end{array}$ \\
\hline Dragendorffs & 0.892 & Yellow & 0.865 & - & 0.827 & - \\
\hline Folin-ciocalteau & 0.843 & Blue & 0.784 & - & 0.746 & - \\
\hline $\begin{array}{l}\text { Diazotized } \\
\text { Sulphanilic } \\
\text { acid }\end{array}$ & 0.842 & Orange & 0.589 & - & 0.637 & - \\
\hline & 0.705 & - & & - & - & & - \\
\hline $\begin{array}{l}\text { Vanillin- } \\
\text { Sulphuric acid }\end{array}$ & 0.827 & - & 0.876 & Green & 0.892 & - \\
\hline
\end{tabular}

Table.3 Effect of different compounds on inhibition of egg hatching of M. incognita

\begin{tabular}{|l|c|}
\hline \multicolumn{1}{|c|}{ Compounds } & Per cent inhibition \\
\hline Phenols (Diazotized sulphanilic acid) & 92 \\
\hline Phenols (Folin-ciocalteau) & 94 \\
\hline Alkaloids & 100 \\
\hline Unsaturated terpenoids & 6 \\
\hline
\end{tabular}


Table.4 Influence of different compounds on juvenile mortality of M. incognita

\begin{tabular}{|l|c|c|c|}
\hline \multirow{2}{*}{\multicolumn{1}{|c|}{ Compounds }} & \multicolumn{3}{|c|}{ Mortality (\%) } \\
\cline { 2 - 4 } & $1^{\text {st }}$ day & $2^{\text {nd }}$ day & $3^{\text {rd }}$ day \\
\hline Phenols (Diazotized Sulphanilic acid) & 82 & 100 & 100 \\
\hline Phenols (Folin-ciocalteau) & 85 & 100 & 100 \\
\hline Alkaloids & 92 & 100 & 100 \\
\hline Unsaturated terpenoids & 5 & 7 & 10 \\
\hline Control & - & - & 8 \\
\hline
\end{tabular}

Effectiveness of active compounds on egg hatching and juvenile mortality

The compounds such as phenol, alkaloids and unsaturated terpenoids were tested on egg hatching and juvenile mortality (Table 3 and 4). Among the compounds alkaloids eluted from $\mathrm{Rf}$ value 0.892 showed cent per cent inhibition of egg hatching and increased $M$. incognita juvenile mortality. Phenols eluted from Rf value of 0.842 (diazotized sulphanilic acid) and $\mathrm{Rf}$ value of 0.843 (folinciocalteau reagent) showed inhibition of egg hatching as well as increased juvenile mortality. The unsaturated terpenoids did not show any inhibition on egg hatching and juvenile mortality of root knot nematode.

Lippianodiflora is an evergreen plant having many medicinal properties. Earlier studies on alcoholic extracts of rhizome showed good antihelmintic activity against Ascaris lumbricoides in human beings under in vitro condition (Raj, 1975). The preliminary studies made on $L$. nodiflora showed possession of nematicidal properties against eggs and juveniles of root knot nematode Meloidogyne incognita. The protein and non protein parts separated from the aqueous leaf extract tested further for their effect on hatching revealed that non protein part from leaves of $L$. nodiflora possessing nematicidal action. Thin layer Chromatography was used to identify and isolate the nematicidal compound present in the non protein part of the leaves. Phenols at Rf value 0.843 (blue) and 0.842 (orange), alkaloids at 0.892 (yellow) and terpenoids at 0.876 (green) spots were identified. Terpenoids present in chloroform extract, whereas phenols and alkaloids present in pertroleum ether extract of leaves. Alkaloids and phenols were found to inhibit the egg hatching and increase juvenile mortality when compared to terpenoids. In the present studies alksloids and phenols were found to be responsible for nematicidal activity against root knot nematode $M$. incognita juveniles. Further studies on this line may throw light on feasibility of evolving commercial botanical pesticides against root knot nematode.

\section{References}

Braford, M.M. 1976. A rapid and sensitive method for quantification of microgram Quantities of protein utilizing the principle of protein dye binding. Ann. Biochem., 72: 248-254.

Srivastava, V.K. and K.K. Srivastava, 1991. Introduction to chromatography: theory ad practice, Chand Company Ltd, New Delhi, $154 \mathrm{p}$

Raj, R.K., 1975. Screening of indigenous plants for anthelmintic action against human Ascaris lumbricoides: Part-II, Indian Journal of physiol Pharmacol. 19 (1):

\section{How to cite this article:}

Senthilkumar, T. and Ramakrishnan, S. 2018. Isolation and Identification of Nematicidal Principle in Lippia nodiflora against Root Knot Nematode Meloidogyne incognita. Int.J.Curr.Microbiol.App.Sci. 7(12): 2616-2620. doi: https://doi.org/10.20546/ijcmas.2018.712.296 